\title{
ANALISIS KAPASITAS TAMPUNG PADA LAHAN BASAH SEI KELIK KETAPANG
}

\author{
Hari Wibowo ${ }^{1)}$ \\ 1) Jurusan Teknik Sipil FT UNTAN, J1. Prof H Hadari Nawawi, Pontianak, Kalimantan Barat
}

\begin{abstract}
Wetlands have a very important role for humans and the environment. The function of wetlands as a support for human life, among others, water sources, a variety of habitats for living things, controlling floods, and drought. One of the wetlands in the Kelik river, Ketapang Regency. This wetland has an area of 2600 ha. The land is now a conservation area, with cultivation rights. The existing problem, namely, the land is the residual combustion that occurred in 2015 and is always flooded with water and the need for an existing drainage system on the land. Land needs to be managed properly in water management. Efforts to manage conservation areas so as not to experience drought, which results in fires, which will threaten land conservations. Methods for dealing with drainage systems by utilizing existing ditches or drains. Drainage design using hydrological and hydraulic studies. The method used in determining the flood discharge plan is based on the need for drainage modulus and the area of the ArcGIS software aid sub-area. The results of the study indicate the need to improve the existing channel. Repair through efforts to deepen the trenches and hold widening or normalization. Also, the depth of the new channel is needed to make an automatic door so that the water can be grounded to maintain the availability of water in the ground.
\end{abstract}

Key Words: conservation land, peat, water system

\section{PENDAHULUAN}

Lahan basah memiliki peranan yang sangat penting bagi manusia dan lingkungan (Irsal Las dan Setiyanto, 2006; Noor, 2001). Fungsi lahan basah, sebagai pendukung kehidupan secara langsung, Namun, juga memiliki berbagai fungsi ekologis seperti pengendali banjir dan kekeringan, serta penyedia unsur hara (Irsal Las dan Setiyanto, 2006; Minardi, 2009; Mulyani dkk., 2009). Lahan basah terdapat di Desa Sei Kelik Kabupaten Ketapang. Lahan basah ini memiliki luas sebesar \pm 2600 ha. Lahan basah Sei Kelik sekarang merupakan kawasan konservasi dengan Hak Guna Usaha (HGU).

Daerah sebelah selatan lahan konservasi selalu tergenang oleh air. Hal ini dikarenakan hujan dan drainase buruk (sebagian lahan tergenang). Selain itu, lahan tidak dipengaruhi pasang surut dan salinitas. Tanaman sebagian besar tidak tumbuh dengan baik, hanya berupa tanaman perdu dan sisa hasil pembakaran hutan.

Kondisi tanah terdiri dari lempung berpasir, laterit, dan sebagian gambut. Lokasi sebagian besar masih merupakan hutan sisa pembakaran dan semak belukar, tegalan, kebun karet, dan kelapa sawit. Sarana irigasi seperti saluran dan bangunan air layaknya daerah rawa. Wilayah ini belum dilengkapi dengan sistem tata air, hanya berupa gorong-gorong untuk pembuangan airnya. Lokasi ini dilewati oleh Sungai Kayong dan Sungai Pawan. Sungai ini mempunyai air yang berwarna coklat, sebagai akibat dari adanya lahan gambut pada daerah hulunya. Secara alami lahan kajian lebih di dominasi limpasan hujannya (run off), kemiringan lahan semuanya menuju ke sungai.

Dari hasil informasi lapangan, diperoleh permasalahan terkait dengan genangan di lahan. Selanjutnya, disajikan hasil analisis dan evaluasi data yang akan digunakan sebagai bahan kajian analisis kapasitas penampang saluran pada daerah lahan basah Sei Kelik di Kabupaten Ketapang.

\section{METODOLOGI}

\section{Sistem Informasi Geografis (SIG)}

Sistem Informasi Geografi merupakan sistem yang berbasiskan komputer untuk menyimpan dan memanipulasi informasi geografis (Aronoff, 1989). SIG memiliki tiga karakteristik dasar, yaitu: (1) mempunyai fenomena aktual (variabel data) yang berhubungan dengan topik permasalahan di lokasi bersangkutan; (2) merupakan suatu kejadian di suatu lokasi; dan (3) mempunyai dimensi waktu (Awangga, 2019).

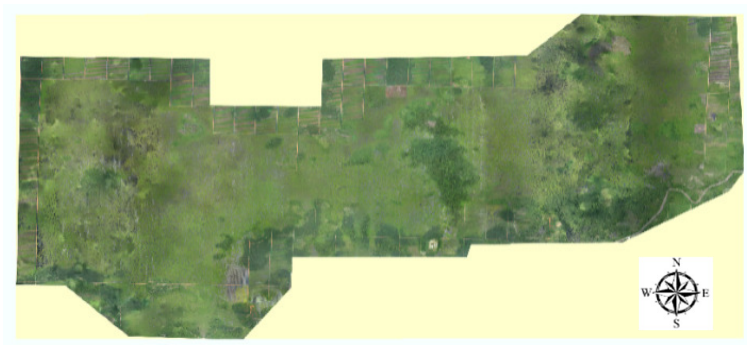

Gambar 1. Peta Foto Udara pada Lokasi Pengamatan 
Peta produktivitas lahan dibuat dari spasial peta penutupan lahan terhadap data atribut produktivitas pertanian. Data produktivitas pertanian sebelumnya diklasifikasi menurut kelas produktivitas. Klasifikasi tutupan lahan berupa sawah, ladang, dan kebun/perkebunan dijadikan sebagai acuan untuk pembuatan peta. Proses pembuatan peta produktivitas lahan dilakukan dengan bantuan software ArcGIS 9.3. Berdasarkan Gambar 1, lokasi dipisahkan menjadi beberapa sub das, seperti tersaji dalam Tabel 1.

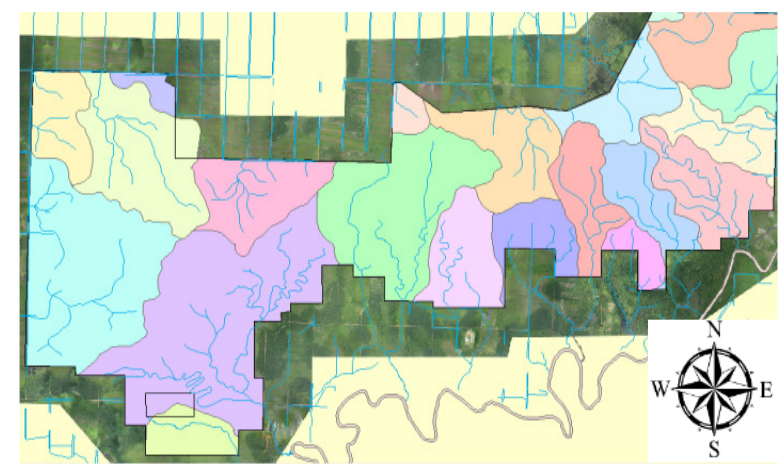

Gambar 2. Peta Sub - Das Lokasi Pengamatan

Tabel 1. Luas Sub Das pada Lahan Konservasi Sei Kelik berdasarkan Data Ketinggian

\begin{tabular}{llccc}
\hline No & DAS & Zona & Luas_Ha & \% \\
\hline 0 & Sub_das 1 & 1 & 345.247 & $60-90$ \\
1 & Sub_das 2 & 2 & 24.162 & $0-30$ \\
2 & Sub_das 3 & 3 & 126.792 & $30-60$ \\
3 & Sub_das 4 & 4 & 96.859 & $30-60$ \\
4 & Sub_das 5 & 5 & 5.631 & $0-30$ \\
5 & Sub_das 6 & 6 & 101.635 & $0-30$ \\
6 & Sub_das 7 & 7 & 92.120 & $0-30$ \\
7 & Sub_das 8 & 8 & 73.749 & $0-30$ \\
8 & Sub_das 9 & 9 & 131.968 & $30-60$ \\
9 & Sub_das 10 & 10 & 90.241 & $30-60$ \\
10 & Sub_das 11 & 11 & 99.683 & $30-60$ \\
11 & Sub_das 12 & 12 & 71.617 & $0-30$ \\
12 & Sub_das 13 & 13 & 112.731 & $30-60$ \\
13 & Sub_das 14 & 14 & 280.047 & $30-60$ \\
14 & Sub_das 15 & 15 & 132.346 & $30-60$ \\
15 & Sub_das 16 & 16 & 60.089 & $0-30$ \\
16 & Sub_das 17 & 17 & 445.598 & $30-60$ \\
17 & Sub_das 18 & 18 & 84.543 & $30-60$ \\
18 & Sub_das 19 & 19 & 22.367 & $0-30$ \\
19 & Sub_das 20 & 20 & 215.348 & $60-90$ \\
20 & Sub_das 21 & 22 & 34.380 & $0-30$ \\
21 & Sub_das 22 & 22 & 0.996 & $0-30$ \\
\hline
\end{tabular}

\section{Analisis Frekwensi Curah Hujan Harian Maksimum}

Persamaan umum analisis frekuensi data dengan Metoda Gumbel, adalah:

Dimana:

$$
\mathrm{X}_{\operatorname{Tr}}=\overline{\mathrm{X}}+\mathrm{K} . \mathrm{S}
$$

$$
\mathrm{X}_{\mathrm{Tr}}=\text { curah hujan rencana }(\mathrm{mm} / \mathrm{hr})
$$

$$
\begin{aligned}
\mathrm{Tr}= & \text { perioda ulang } \\
\mathrm{X} & =\text { harga rata-rata }(\mathrm{mm} / \text { hari }) \\
\mathrm{K} & =\text { faktor frekwensi, } \mathrm{K}=0.78(-\ln (-\ln (1- \\
& 1 / \text { Tr })))-0.45 \\
\mathrm{~S} \quad= & \text { standar deviasi }
\end{aligned}
$$

\section{Perhitungan Evapotranspirasi}

Dalam menghitung evapotranspirasi potensial, banyak metode yang bisa digunakan. Salah satu metode untuk menghitung evapotranspirasi potensial yang paling sering dipakai yaitu metode Penman-Monteith (Nasional, 2004)

$$
\begin{aligned}
\mathrm{Rn}= & \{(1-\alpha) \cdot(0.25+0.50 \mathrm{n} / \mathrm{N})\}-\left\{\left(\mathrm{Tk}^{4} .\right.\right. \\
& (0.34-0.044 \sqrt{\mathrm{e} d}) \cdot(0.1+0.9 \mathrm{n} / \mathrm{N})\}
\end{aligned}
$$

dimana

$$
\begin{array}{ll}
\alpha= & \text { Albedo } \\
\mathrm{M} & =\text { Bulan ke-n } \\
\mathrm{N} & =\text { Jumlah hari bulan } \mathrm{n} \\
\mathrm{n} / \mathrm{N}= & \text { perbandingan jam penyinaran matahari } \\
& \text { yang terjadi dengan yang mungkin } \\
\mathrm{e}_{\mathrm{d}}= & \text { tekanan uap pada suhu yang ada, dalam } \\
& \mathrm{mm} / \text { hari (ed }=\text { Rh } \mathrm{x} \mathrm{ea}) \\
\mathrm{f}(\mathrm{T})= & \mathrm{Tk} \\
\mathrm{f}\left(\mathrm{e}_{\mathrm{d}}\right)= & 0.34-0.044 \mathrm{e}_{\mathrm{d}} \\
\mathrm{f}(\mathrm{n} / \mathrm{N})= & 0.1+0.9 \mathrm{n} / \mathrm{N} \\
\mathrm{Ea}= & \{0.27(1+\mathrm{u} / 100)\} \text { (ea }- \text { ed) } \\
\mathrm{f}(\mathrm{T})= & \text { faktor suhu/ konstanta Bloztman. } \\
\mathrm{f}\left(\mathrm{e}_{\mathrm{d}}\right)= & \text { faktor kelembaban }
\end{array}
$$

\section{Modul Drainase}

Besarnya modul drainase dihitung dengan mengambil besar hujan maksimum harian untuk perioda ulang 2,5,10, 20 dan 50 Tahun. Modul drainase dihitung dengan asumsi terjadinya hujan harian maksimum 1 harian, 3 harian dan 6 harian (hari) berturutan dan harus dibuang dalam waktu 1 , 3, dan 6 harian juga. Rumusan modul drainase, terlihat pada Persamaan 3.

$$
\mathrm{D}(\mathrm{n})=\mathrm{R}(\mathrm{n})-\mathrm{n}(\mathrm{ETo}+\mathrm{P})-\mathrm{S}
$$

Dimana:

$$
\begin{aligned}
& \mathrm{R}(\mathrm{n})=\text { jumlah hujan dari } \mathrm{n} \text { hari }(\mathrm{mm}) \\
& \mathrm{S}=\text { storage } \\
& \mathrm{n}=\text { jumlah hari } \\
& \mathrm{P}=\text { perkolasi }(\mathrm{mm} / \mathrm{hari}) \\
& \text { Eto }=\text { evaporatranspirasi }(\mathrm{mm} / \mathrm{hari}) \\
& \mathrm{Dn}=\text { modulus drainase }(\mathrm{mm} / \mathrm{hr})
\end{aligned}
$$

Debit modulus drainase (Dm) didefinisikan sebagaimana Persamaan 4.

$$
\mathrm{Dm}=\frac{\mathrm{D}(\mathrm{n})}{\mathrm{n} .8,64}(\mathrm{liter} / \mathrm{detik} / \mathrm{Ha})
$$




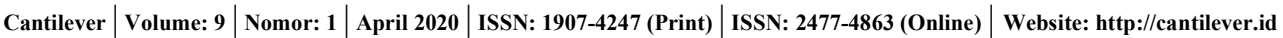

Hari Wibowo $\mid$ Analisis Kapasitas Tampung pada Lahan Basah Sei Kelik Ketapang

\section{Perhitungan Debit Rencana pada Daerah Pengaliran}

Debit rencana adalah besarnya debit pada periode ulang tertentu yang diperkirakan akan melalui bangunan air yang telah direncanakan. Metode yang digunakan dalam menentukan debit banjir rencana berdasarkan kebutuhan Modulus Drainase, sebagaimana terlihat dalam Persamaan 5.

$$
\mathrm{Q}=1,62 \cdot \mathrm{Dm} \cdot \mathrm{A}^{0.92}
$$

dimana ;

$\mathrm{Q}=$ debit rencana $\left(\mathrm{m}^{3} /\right.$ detik $)$

$\mathrm{A}=$ luas daerah tangkapan $(\mathrm{Ha})$

$\mathrm{Dm}=$ debit modulus drainase $(\mathrm{lt} / \mathrm{dt} / \mathrm{ha})$

\section{Analisis Kapasitas Saluran pada Daerah Lahan} Basah Sei Kelik

Perencanaan dimensi saluran diasumsikan, bahwa pembuangan air dari lahan tersebut akan habis selama tidak ada genangan. Dalam perhitungannya dengan menggunakan persamaan untuk aliran steady dari Manning. Rumus yang digunakan terlihat dalam Persamaan 6.

$$
\text { Kapasitas Saluran }(\mathrm{Q})=\text { VA }\left(\mathrm{m}^{3} / \mathrm{det}\right)
$$

Dimana:

$$
\begin{array}{ll}
\text { Kecepatan }(\mathrm{V}) & =1 / \mathrm{n} \mathrm{R}^{2 / 3} \mathrm{~S}^{0.5}(\mathrm{~m} / \text { detik }) \\
\text { Jari-jari Hidraulis }(\mathrm{R}) & =\mathrm{A} / \mathrm{P}(\mathrm{m}) \\
\text { Luas Penampang (A) } & =(\mathrm{b}+\mathrm{m} \cdot \mathrm{h}) \cdot \mathrm{h}\left(\mathrm{m}^{2}\right)
\end{array}
$$

\section{HASIL DAN PEMBAHASAN Pengumpulan Data}

Salah satu dari survey yang mendukung kajian ini adalah data hidrologi dan hidrometri. Data hidrologi yang diperlukan berupa data curah hujan harian, baik curah hujan harian maksimum maupun curah hujan efektif. Curah hujan harian maksimum diperlukan untuk analisis limpasan atau analisis banjir (modul drainase), serta data curah hujan diperlukan untuk analisis kebutuhan air.

Tabel 2. Rekapitulasi Data Klimatologi Stasiun Ketapang (1986-2016) Kabupaten Ketapang

\begin{tabular}{lcccccccccccc}
\hline \multicolumn{1}{c}{ Parameter } & \multicolumn{10}{c}{ Bulan } & \multicolumn{10}{c}{$\mathbf{1 0}$} & $\mathbf{1 1}$ & $\mathbf{1 2}$ \\
\cline { 2 - 11 } & $\mathbf{1}$ & $\mathbf{2}$ & $\mathbf{3}$ & $\mathbf{4}$ & $\mathbf{5}$ & $\mathbf{6}$ & $\mathbf{7}$ & $\mathbf{8}$ & $\mathbf{9}$ & $\mathbf{1 0}$ & $\mathbf{1 1}$ \\
\hline Data Temperatur $\left({ }^{\circ} \mathrm{C}\right)$ & 27.00 & 27.18 & 27.19 & 27.27 & 27.64 & 27.33 & 26.83 & 26.83 & 26.90 & 26.85 & 26.90 & 26.73 \\
Data Kelembaban & 85.98 & 85.06 & 85.84 & 86.88 & 85.40 & 84.63 & 84.15 & 83.21 & 84.05 & 86.07 & 87.06 & 85.61 \\
Penyinaran matahari & 4.83 & 5.12 & 5.10 & 5.20 & 5.82 & 5.95 & 6.21 & 6.27 & 5.61 & 4.60 & 4.65 & 4.41 \\
Kecepatan Angin (knot) & 2.22 & 2.18 & 1.77 & 1.69 & 1.94 & 2.19 & 2.50 & 2.98 & 2.74 & 1.99 & 1.77 & 1.96 \\
Data Penguapan (mm/hr) & 3.60 & 4.30 & 3.90 & 3.39 & 3.26 & 2.78 & 3.16 & 4.17 & 4.02 & 3.42 & 3.20 & 3.27 \\
\hline
\end{tabular}

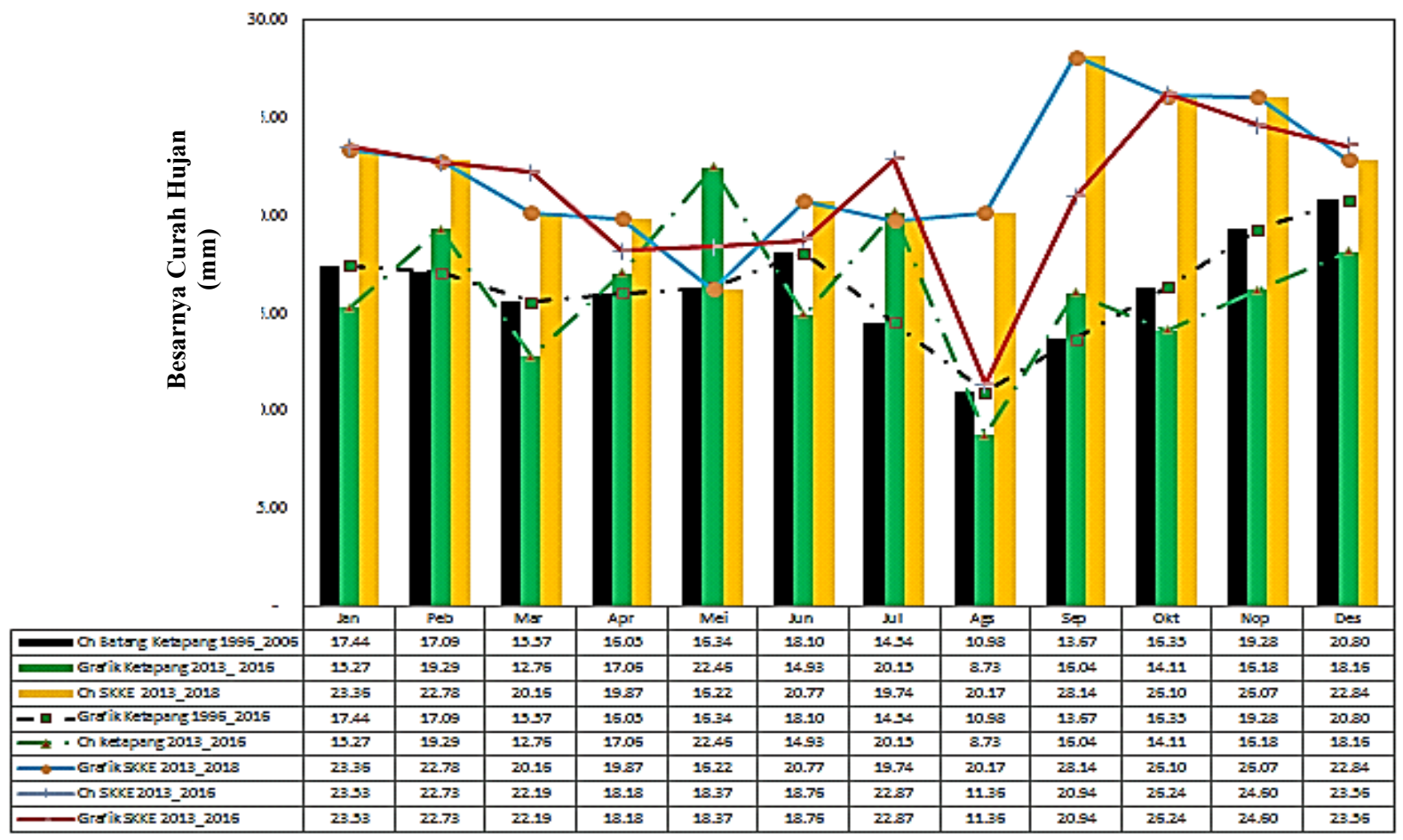

Gambar 3. Perbandingan Curah Hujan Bulanan Rata-Rata Stasiun Ketapang dan SKKE Kebun AMNL 


\section{Hasil Perhitungan Curah Hujan}

Selanjutnya dengan menggunakan Persamaan 1, maka diperoleh hasil curah hujan harian maksimum, seperti pada Tabel 3

Tabel 3. Hasil curah hujan harian maximum untuk perioda ulang " $n$ " tahun metoda gumbel $(\mathrm{mm})$

\begin{tabular}{cccccc}
\hline $\mathbf{T r}$ & $\mathbf{1} \mathbf{h r}$ & $\mathbf{3} \mathbf{h r}$ & $\mathbf{4} \mathbf{h r}$ & $\mathbf{5} \mathbf{h r}$ & $\mathbf{6} \mathbf{h r}$ \\
\hline 2 th & 170,484 & 212,084 & 257,884 & 274,484 & 286,084 \\
5 th & 189,859 & 231,459 & 277,259 & 293,859 & 305,459 \\
10 th & 202,044 & 243,644 & 289,444 & 306,044 & 317,644 \\
20 th & 213,730 & 255,330 & 317,730 & 317,730 & 329,330 \\
50 th & 228,856 & 270,456 & 270,456 & 332,856 & 344,456 \\
\hline
\end{tabular}

\section{Perhitungan Evapotranspirasi}

Rumus Penmman Modifikasi membutuhkan lebih banyak data terukur, yaitu: suhu udara bulanan rerata $\left(\mathrm{t},{ }^{0} \mathrm{C}\right)$, kelembaban relatif bulanan rerata $(\mathrm{RH}$, $\%)$, kecerahan matahari bulanan $(\mathrm{n} / \mathrm{N}, \%)$, kecepatan angin bulanan rerata $(\mathrm{u}, \mathrm{m} / \mathrm{s})$, dan letak lintang daerah yang ditinjau. Perhitungan ETo berdasarkan rumus Penmann di daerah Indonesia

Tabel 4. Resume Hasil Perhitungan Evapotranspirasi pada Stasiun Ketapang

\begin{tabular}{lcc}
\hline \multirow{1}{*}{ Bulan } & \multicolumn{2}{c}{ Evapotranspirasi } \\
\cline { 2 - 3 } & $\mathrm{mm} /$ hari & $\mathrm{mm} /$ bulan \\
\hline Januari & 3,88 & 120,34 \\
Pebruari & 3,74 & 104,82 \\
Maret & 4,37 & 135,46 \\
April & 4,22 & 126,73 \\
Mei & 3,80 & 117,91 \\
Juni & 3,44 & 103,14 \\
Juli & 4,29 & 133,10 \\
Agustus & 3,63 & 112,46 \\
September & 3,92 & 117,55 \\
Oktober & 3,15 & 97,67 \\
Nopember & 3,46 & 103,72 \\
Desember & 3,58 & 110,89 \\
\hline
\end{tabular}

\section{Modul Drainase}

Modul drainase dihitung dengan asumsi terjadinya hujan harian maksimum 1 harian, 3 harian dan 6 harian (hr) berturutan dan harus dibuang dalam waktu 1, 3, dan 6 harian.

Tabel 5. Hasil Analisis Modul Drainase (lt/dt/ha)

\begin{tabular}{cccccc}
\hline $\begin{array}{c}\text { Curah Hujan } \\
\text { (R) maks }\end{array}$ & \multicolumn{5}{c}{ TR (Perioda Ulang) dalam Tahunan } \\
\hline (hari kumulatif) & 2 th & 5 th & 10 th & 20 th & 50 th \\
1 harian & 4,59 & 6,83 & 8,24 & 9,60 & 11,35 \\
2 harian & 5,93 & 8,18 & 9,59 & 10,94 & 12,69 \\
3 harian & 9,41 & 11,65 & 13,06 & 14,41 & 16,16 \\
4 harian & 14,71 & 16,95 & 18,36 & 19,71 & 21,46 \\
5 harian & 16,63 & 18,87 & 20,28 & 21,63 & 23,39 \\
6 harian & 17,97 & 20,21 & 21,62 & 22,98 & 24,73 \\
\hline
\end{tabular}

\section{Neraca Air Lahan Konservasi}

Neraca air lahan Tahun Normal, Tahun El Nino dan Tahun La Nina di lokasi terlihat pada Gambar 4 sampai dengan Gambar 7.
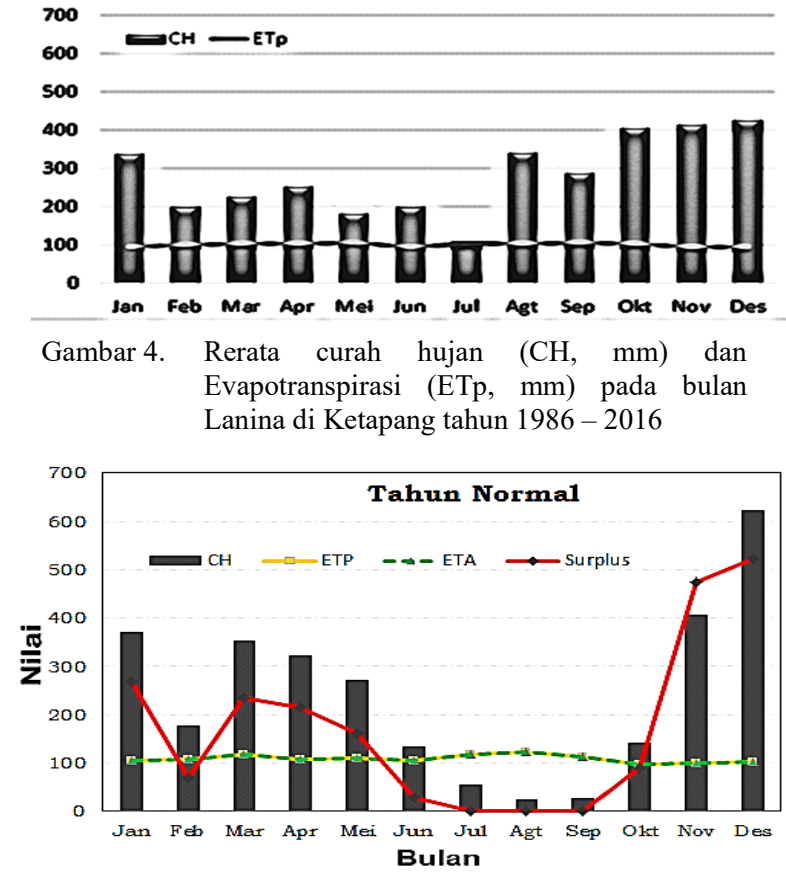

Gambar 5. Neraca Air Lahan pada Tahun Normal

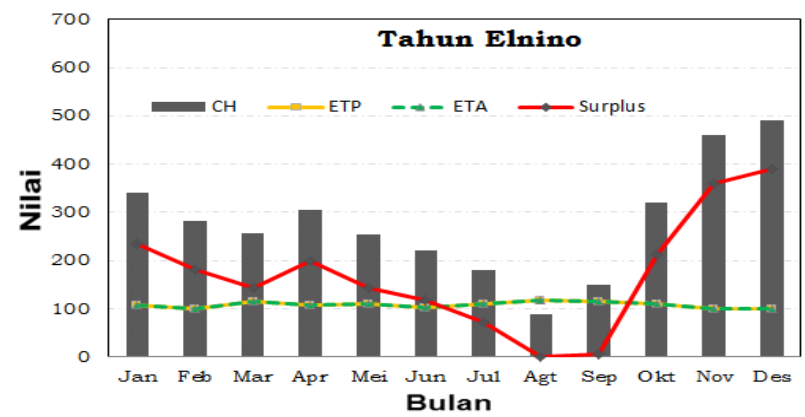

Gambar 6. Neraca Air Lahan pada Tahun El Nino

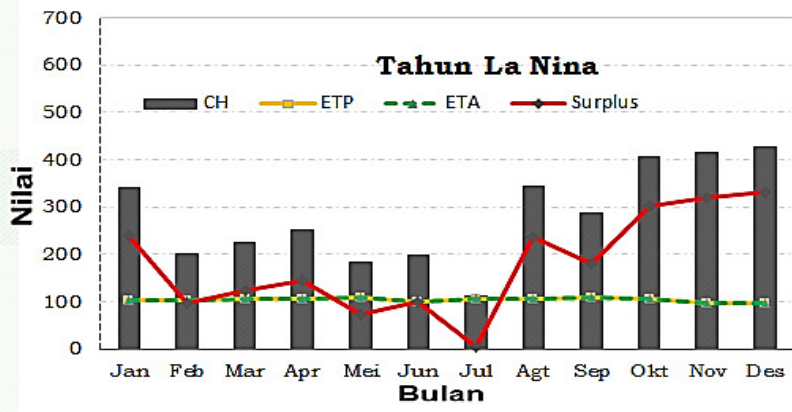

Gambar 7. Neraca Air Lahan pada Tahun La Nina

Gambar 4 sampai dengan Gambar 7 menunjukan bahwa lahan konservasi selalu tergenang oleh air, baik dalam kondisi Normal, El Nino maupun La Nina. 


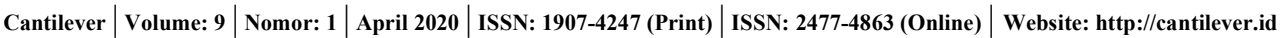

Hari Wibowo | Analisis Kapasitas Tampung pada Lahan Basah Sei Kelik Ketapang

\section{Analisis Pengaruh Pasang Surut Terhadap Lahan}

Pengamatan muka air dengan interval 1 jam, yang dilakukan dalam rentang waktu 15 hari. Perhitungan elevasi muka air dilakukan dengan cara menambahkan harga bacaan peilschaal saat pengamatan dengan harga elevasi posisi nol peilschaal, terhadap sistem referensi topografi yang digunakan. Untuk lokasi dalam kajian ini sistem referensi yang digunakan adalah sistem referensi lokal, sbb:

a) Pengamatan dilakukan pada Titik S. Kayong (Muara menuju Laut Cina Selatan) selama 15 hari mulai 26 Mei s/d 11 Juni 2019. Dari hasil grafik yang dibuat dapat dilihat bahwa saat terjadinya spring tide dan neap tide, yaitu : Spring Tide: 26 Mei - 11 Juni 2019.

b) Menggunakan Metoda French Tidal Studies, harga bilangan Formzal diperoleh dengan Persamaan:

$$
\mathrm{F}=\frac{\mathrm{K}_{1}+\mathrm{O}_{1}}{\mathrm{M}_{2}+\mathrm{S}_{2}}=\frac{0,475+0,057}{0,064+0,402}=1,142
$$

Konstanta Pasang Surut berdasarkan Bilangan Formzal, disajikan dalam Tabel 6.

Tabel 6 Nilai Konstanta Pasang Surut berdasarkan Bilangan Formzal

\begin{tabular}{ll}
\hline $\boldsymbol{F} \leq \mathbf{0 . 2 5}$ & Pasang surut tipe ganda (semidiurnal tides) \\
\hline $\mathbf{0 , 2 5}<\boldsymbol{F} \leq \mathbf{1 . 5}$ & $\begin{array}{l}\text { Pasang surut tipe campuran condong harian ganda } \\
\text { (mixed mainly semidiurnal tides) }\end{array}$ \\
$\mathbf{1 . 5 0}<\boldsymbol{F} \leq \mathbf{3 . 0}$ & $\begin{array}{l}\text { Pasang surut tipe campuran condong harian tunggal } \\
\text { (mixed mainly diurnal tides) } \\
\text { Pasang surut tipe campuran condong harian tunggal } \\
\text { (mixed mainly diurnal tides) }\end{array}$ \\
\hline
\end{tabular}

Dengan harga Formzal $=1,142$ maka tipe pasang surut yang terjadi adalah mixed mainly semidiurnal tides. Hal ini menunjukan bahwa dalam satu hari terjadi dua kali air pasang dan dua kali air surut, tetapi tinggi dan periodenya berbeda. Pada tipe ini, pasang surut campuran condong ke harian ganda. Harga parameter pasang surut yang diperoleh dari hasil analisis di titik pada Sungai Kayong (Tabel 7).

Tabel 7. Tinggi Muka Air Pasang Surut Daerah Muara Sungai Kayong

\begin{tabular}{ll}
\hline \multicolumn{1}{c}{ Jenis Parameter } & Elevasi \\
\hline Higest High Water Spring (HHWS) & $24,7701 \mathrm{~m}$ \\
Mean High Water Spring (MHWS) & $23,7825 \mathrm{~m}$ \\
Mean High Water Level (MHWL & $24,0721 \mathrm{~m}$ \\
Mean Sea Level (MSL) & $23,3660 \mathrm{~m}$ \\
Mean Low Water Level (MLWL) & $22,5359 \mathrm{~m}$ \\
Mean Low Water Spring (MLWS) & $22,8950 \mathrm{~m}$ \\
Lowest Low Water Level (LLWS) & $21.4797 \mathrm{~m}$ \\
\hline
\end{tabular}

Berdasarkan kajian pasang surut, lokasi berada pada daerah yang tidak terkena pasang surut atau lebak. Lokasi pemasangan keller berada pada elevasi $+22.0 \mathrm{~m}$, sedangan pada lahan antara $+26.30 \mathrm{~m}$ sampai dengan $+34.50 \mathrm{~m}$. Hal ini menunjukan bahwa lokasi lebih dipengaruhi curah hujan dibandingkan pasang surut.

\section{Rencana Normalisasi Parit pada Lokasi Kajian}

Rencana saluran di daerah penelitian tersaji dalam Gambar 8.

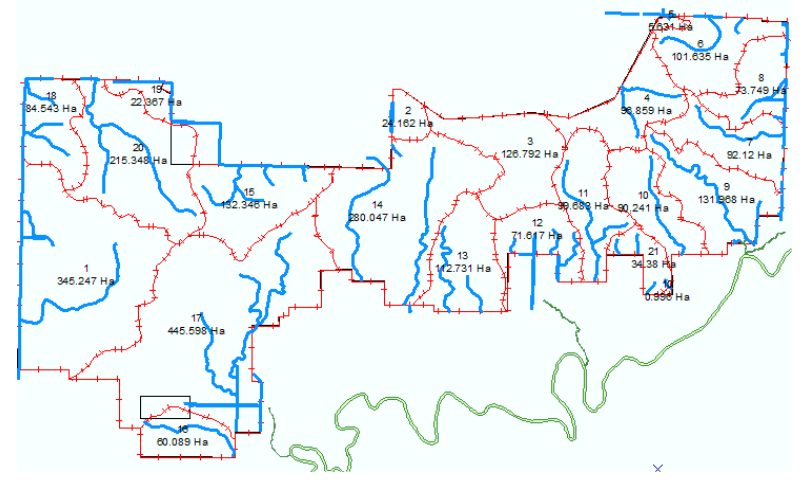

Gambar 8 Rencana Normalisasi Saluran di Lokasi

Berdasarkan kriteria mengenai penjabaran konsep perencanaan yang telah dibuat, dapat diperoleh nilai-nilai kuantitatif yang akan dituangkan dalam gambar perencanaan, dan selanjutnya dapat dijadikan sebagai pedoman dalam pelaksanaan fisik dan pemeliharaan

\section{Koefisien Kekasaran Saluran}

Untuk saluran baru yang direncanakan, kriteria standard kekasaran (Strikler-Manning), tersaji dalam Tabel 8.

Tabel 8. Nilai Koefisien Kekasaran Berbagai Jenis Saluran

\begin{tabular}{ccc}
\hline $\begin{array}{c}\text { Kedalaman } \\
\text { Saluran }\end{array}$ & n- Manning & K-strikler \\
\hline$<1 \mathrm{~m}$ & 0.020 & 50,00 \\
$1-2 \mathrm{~m}$ & 0.018 & 55,56 \\
$2-3 \mathrm{~m}$ & 0.016 & 62,50 \\
\hline
\end{tabular}

Ketentuan-ketentuan mengenai kecepatan ijin, perbandingan lebar dan kedalaman saluran, kemiringan talud (lereng), kofisien kekasaran Manning dan tinggi jagaan adalah berdasarkan pedoman pada Buku Kriteria Perencanaan yang disusun oleh Direktorat Jenderal Pengairan Departemen Pekerjaan Umum. Data pada pembuang arah kiri dan bawah, adalah:

a) Segmen 1:

$$
\begin{aligned}
\text { - } & \text { panjang saluran }=1.900 \mathrm{~m} \\
\text { - } & \text { luas }=84,543 \mathrm{Ha} \\
\text { - } & \text { lebar saluran rata-rata }=2,500 \mathrm{~m}
\end{aligned}
$$


- kedalaman air $=-0,20 \mathrm{~s} / \mathrm{d}-0,50 \mathrm{~m}$

b) Segmen 2:

- panjang saluran $=1.600 \mathrm{~m}$

- luas $=384,25 \mathrm{Ha}$

- lebar saluran rata-rata $=4,0707 \mathrm{~m}$

- kedalaman air $=-0,26 \mathrm{~s} / \mathrm{d}-1,07 \mathrm{~m}$

c) Segmen 3:

- panjang saluran $=965 \mathrm{~m}$

- luas $\quad=445,598 \mathrm{Ha}$
- lebar saluran rata-rata $=3,00 \mathrm{~m}$

- kedalaman air $=-0,16 \mathrm{~s} / \mathrm{d}-1,10 \mathrm{~m}$

d). Segmen 4:

- panjang saluran $=265 \mathrm{~m}$

- luas $\quad=222,78 \mathrm{Ha}$

- lebar saluran rata-rata $=3,00 \mathrm{~m}$

- kedalaman air $=-0,860 \mathrm{~m}$

Tabel 9. Perhitungan Debit Aliran Saluran pada Zona $(A=84,54 \mathrm{Ha})$

\begin{tabular}{ccccccc}
\hline $\begin{array}{c}\text { Curah Hujan } \\
\text { Harian }\end{array}$ & $\begin{array}{c}\text { Periode Ulang } \\
\text { (Tahun) }\end{array}$ & $\begin{array}{c}\text { Curah } \\
\text { Hujan }(\mathbf{m m})\end{array}$ & \multicolumn{2}{c}{$\begin{array}{c}\text { Modulus Drainase } \\
\text { (liter/det/ha) }\end{array}$} & $\begin{array}{c}\text { Luas } \\
\text { (m3/det/ha) }\end{array}$ & $\begin{array}{c}\text { Debit Banjir } \\
\text { (ha) }\end{array}$ \\
\hline 6 harian & 50 & 228.8557 & 24.73 & 0.025 & 84.54 & 2.375 \\
& 50 & 344.456 & 24.73 & 0.025 & 384.247 \\
& 50 & 344.456 & 24.73 & 0.025 & 445.60 & 10.956 \\
& 50 & 344.456 & 24.73 & 0.025 & 222.799 & 5.791 \\
& 50 & 344.456 & 24.73 & 0.025 & 215.35 \\
& 50 & 344.456 & 24.73 & 0.025 & 60.09 & 1.735 \\
\hline
\end{tabular}

Tabel 10. Perhitungan Dimensi Saluran pada Zona $(\mathrm{A}=84,54 \mathrm{Ha})$

\begin{tabular}{cccccccc}
\hline $\begin{array}{c}\text { Lebar } \\
\mathbf{b}(\mathbf{m})\end{array}$ & $\begin{array}{c}\text { Kedalaman } \\
(\mathbf{y}) \mathbf{~ m}\end{array}$ & $\begin{array}{c}\text { Koef Manning } \\
(\mathbf{n})\end{array}$ & jarak & $\begin{array}{c}\text { Kemiringan } \\
(\mathbf{S})\end{array}$ & $\begin{array}{c}\text { Kecepatan } \\
(\mathbf{m} / \mathbf{d e t i k})\end{array}$ & $\begin{array}{c}\text { Debit } \\
(\mathbf{m} 3 / \mathbf{d e t})\end{array}$ & $\begin{array}{c}\text { Debit } \\
\text { Banjir }\end{array}$ \\
\hline $\mathbf{2 . 5 0 0}$ & 1.547 & 0.018 & 1.900 & 0.00020 & 0,614 & 0,376 \\
$\mathbf{4 . 2 0 0}$ & 2.617 & 0.018 & 1.600 & 0.00020 & 0,870 & 9,562 & 9,375 \\
$\mathbf{5 . 0 0 0}$ & 2.430 & 0.018 & 965 & 0.0002 & 0,903 & 10,973 & 10,958 \\
$\mathbf{4 . 0 0 0}$ & 1.882 & 0.018 & 265 & 0.0002 & 0,770 & 5,794 & 5,791 \\
$\mathbf{3 . 5 0 0}$ & 2.120 & 0.018 & 1800 & 0.0002 & 0,764 & 5,668 & 5,613 \\
$\mathbf{3 , 0 0}$ & 1,03 & 0.018 & 700 & 0.0002 & 0,570 & 1,747 & 1,735 \\
\hline
\end{tabular}

\section{KESIMPULAN}

Dari hasil identifikasi, penelusuran masalah, serta kajian dan desain pada DR Konservasi Sei Kelik, maka dapat disimpulkan hal-hal sebagai berikut:

a) Berdasarkan evaluasi lahan pada DR Konservasi Sei Kelik Kabupaten Ketapang ini, dapat disimpulkan bahwa sebagian besar merupakan lembah yang tergenang (drainase dan potensi drainase buruk). Terdapat dua faktor yang menyebabkan buruknya drainase di lokasi ini, salah satunya akibat saluran drainase yang tidak memadai. Meskipun lahan tidak terluapi pasang karena tidak adanya akses secara langsung ke Sungai Kayong, namun potensi drainase lahan ini sangat sulit/kecil. Banjir yang terjadi mempunyai durasi cukup panjang dan dapat membahayakan tanaman untuk dapat tumbuh dengan baik.

b) Untuk memperbaiki dan memulihkan vegetasi yang rusak, perlu dilakukan normalisasi pada parit-parit alamiah, dengan cara mendalamkan maupun memperbesar kapasitas tampung pada penampangan saluran.

c) Perlu perbaikan pada saluran yang ada, karena tidak cukup menampung kelebihan air buangan pada lahan konservasi, berupa pelebaran maupun pendalaman pada saluran yang ada.

\section{UCAPAN TERIMA KASIH}

Ucapan terima kasih kepada Fakultas Teknik Universitas Tanjungpura, yang telah membiayai kegiatan ini dengan dana DIPA Fakultas.

\section{REFERENSI}

Aronoff, S. (1989). Geographic Iformation Systems. A management perspective, 1989.

Awangga, R. M. (2019). Pengantar Sistem Informasi Geografis: Sejarah, Definisi Dan Konsep Dasar. Kreatif.

Irsal Las, K. S., \& Setiyanto, A. (2006). Isu Dan Pengelolaan Lingkungan Dalam Revitalisasi Pertanian. Jurnal Litbang Pertanian, 25(3), 107.

Minardi, S. (2009). Optimalisasi Pengelolaan Lahan Kering Untuk Pengembangan Pertanian Tanaman Pangan.

Mulyani, A., Rachman, A., \& Dairah, A. (2009). Penyebaran Lahan Masam, Potensi dan Ketersediaannya untuk Pengembangan Pertanian. Buku fosfat alam: Pemanfaatan fosfat alam yang digunakan langsung sebagai pupuk sumber P (32p). Bogor: Balai Penelitian Tanah.

Nasional, B. S. (2004). Tata cara penghitungan evapotranspirasi tanaman acuan dengan metode Penman-Monteith. RSNI T-01-2004. Jakarta: Departemen Permukiman dan Prasarana Wilayah.

Noor, M. (2001). Pertanian Lahan Gambut, Potensi dan Kendala. Kanisius. 